\title{
The Cultivation of English Intercultural Communication Ability Based on College Students' Cognitive Level Development
}

\author{
Linhui Wu \\ Chengdu Neusoft University, Chengdu, Sichuan, 611844
}

Keywords: Cognitive level; Intercultural communication; college English teaching;

\begin{abstract}
Piaget believed that "learning belongs to development" and "education belongs to the development level of the educated". He argued that teaching must take into account the development stage of the students at that time. College English education and teaching reform must also consider the cognitive development status of college students, and the setting of college English courses, construction of English textbooks and teaching plans should be adapted to students' cognitive development stage. The fundamental purpose of foreign language teaching is to achieve intercultural communication and to communicate with people from different cultural backgrounds. In this paper, under the precondition of the development of the college students' cognitive level, from the concept of intercultural communication and analyzed from the perspective of the relationship between culture and language cultural differences impact on intercultural communication, this paper discusses in college English teaching practice, teachers should pay attention to culture teaching and language teaching, so as to comprehensively improve the quality of college English teaching, and greatly improve the students' intercultural communicative competence.
\end{abstract}

\section{Introduction}

Self-cognition is the reflection of the subject to its own state and its relationship with the outside world. It is generated in social practice and plays an important role in the practice of the subject. The formation of self-cognition is the precondition for the subject to understand and transform the world. The cultivation of college students' self-cognitive ability should aim at perfecting students' individual consciousness and forming a rational understanding of their relationship with the outside world. Culture is the way of life of a group. It includes everything that people have learned since birth, such as language, manners and contents, beliefs, as well as the material and spiritual foundations on which people live. The concept of culture covering such a wide range is usually divided into three levels: "the first level is material culture, which has been processed and transformed by people's subjective consciousness. The second level is institutional culture, which mainly includes political system, economic system, law, literary and artistic works, interpersonal relationship and habit behavior. The third level is psychological culture, or concept culture, including human values, thinking mode, aesthetic taste, moral sentiment, religious emotion and national psychology. Language and culture are part and whole. Language is the carrier of culture and an integral part of culture. Language itself is the most outstanding culture created by human beings. Language is a symbol of human culture. At the same time, language is the symbol of community. Language is a form of culture. It is impossible to learn English well without understanding British and American culture. Therefore, the deeper and more detailed understanding of the history, culture, tradition, custom, way of life and details of the language learning, the more able you will be to correctly understand and use the language.

\section{The influence of cultural differences on intercultural communication}

In the field of linguistics, intercultural communicative competence includes linguistic competence and socio-cultural competence. Language competence includes vocabulary, grammar, speech system, etc. Socio-cultural competence includes capacity for doing things, communication, 
knowledge and application. The ability to deal with affairs refers to the ability to abandon ethnocentrism and emotion when the communicative subject communicates with the communicative object from other cultures. Knowledge system refers to the cultural reference system, such as politics, economy, customs, etiquette, etc. Ability to use refers to the ability to integrate work, communication and knowledge systems.

According to intercultural communication, intercultural communication competence includes :(l) basic communication competence system; (2) emotional and relational ability system; (3) plot ability system; (4) strategic capability system. Wolfson has said that unconscious grammatical, phonetic and lexical errors may indicate that the speaker has not mastered language ability and can be understood and accepted. However, if a person speaks good English but has pragmatic errors, such as an inappropriate question, an untimely apology, and an inappropriate response to others' praise, he will be regarded as uncultured, thus causing unhappiness and even communication failure. Chinese students learning English didn't learn the language environment, so the understanding of the social meaning of language, and learn to appropriate use of language in various situation can only be acquired from classroom teaching, which requires teachers to teach language at the same time, must not ignore the students' learning and understanding of English-speaking country social customs, value orientation, speech rules, and nonverbal communication way, otherwise not cultivate cross-cultural awareness, improve communication skills. It can be seen that the cultivation of students' intercultural communication ability is extremely important in college English teaching.

\section{The cognitive level of college students in college English teaching}

There are great differences between eastern and western cultures in religious belief, cultural tradition, value orientation, local customs and practices, way of life and way of thinking. The process of learning a foreign language is to realize the dialogue and communication between two consciousness and two cultures. Chinese and English also have great differences in terms of language expression, idea expression and cultural characteristics. These differences make it difficult to learn English and cross-cultural communication. These difficulties are reflected in the lack of understanding of western religious beliefs and cultural allusions, the inadaptability to western ways of thinking, the ignorance of western language taboos, the difficulty in understanding western literature, the lack of understanding of English idioms and the rejection of western communication. In college English teaching, we are relatively short of knowledge imparting and training. For a long time, college English teaching has focused on the teaching of language knowledge, ignoring the interaction between language use and cross-cultural communication, paying too much attention to language form and ignoring the application of language in practical situations. As a result, although cet- 4 and cet- 6 grades have been improved every year, we may have made great progress in foreign language teaching, but the students we have cultivated have difficulty in listening and speaking, and cross-cultural communication is not enough.

Due to the traditional teaching method and the influence of structural linguistics and psycholinguistics, in the history of China's foreign language education, language and culture are separated or connected to a little, only pay attention to language form, completely out of the social and cultural context of pure language skills training, drilling and other mechanical practice the sentence pattern with college English textbooks. In recent years, with the deep reform of teaching method, to some new teaching methods such as method, the use of communicative approach, is the teaching emphasis shift from imparting language knowledge to language ability, and for the cultivation of intercultural communicative competence effort is not enough, we should truly realize the goal of college English teaching is to cultivate talents in cross-cultural communication. In the teaching of college English in quite a few universities, there are no courses on western culture, history, anthropology and sociology. Students cannot understand the culture of other countries, nor can they grasp some concepts and guiding principles related to culture. In addition, most college English teachers in China have not received formal training in intercultural communication, and they can only learn this knowledge through personal exploration and accumulation of experience. Therefore, this situation is far from enough to meet the actual needs of contemporary intercultural 
communication.

\section{How to cultivate students' intercultural communication ability in college English teaching}

The above discussion clearly shows that it is immeasurable for college English teachers to cultivate students' intercultural communicative ability consciously in the teaching process. College English teachers should fully mobilize the enthusiasm and initiative of students and enable them to participate more and better in teaching, so as to change the current teaching mode with language knowledge as the core.

Linguist Wenzhong $\mathrm{Hu}$ recommended the following methods: (l) add elements of western customs and patterns of behavior in the text; (2) organize students to discuss the differences in cultural customs of different ethnic groups and regions in China; (3) use English videos and movies for teaching, and then organize discussions; (4) encourage students to communicate with foreigners; (5) ask students to read some short stories or scripts, and write down meaningful cultural details; (6) ask students to read more books about cross-cultural communication. Classroom teaching is the main way to cultivate students' intercultural communication ability. By using these methods, to cultivate the students' cross-cultural communication ability in the teaching of college English teachers should do: 1 . To cultivate students in self check before the text related background knowledge, presentation in class, this way will encourage those poor language skills, personality is introverted students dare not speak, let them be prepared to speak, so as to overcome their psychological ashamed to speak; In addition, by collecting materials, they can improve their understanding of the cultural knowledge of English-speaking countries.

In the process of classroom teaching, teachers increase the frequency of presentation and enhance the interaction between teachers and students, so that students can better integrate into classroom teaching activities. The teacher can connect the content of the text with the students' real life, which can arouse the students' interest and make them feel the words have something to say. To the student's answer, the teacher must make the same to go different, avoids the criticism and the condemnation. In this way, students can be kept and motivated to learn foreign languages, teachers and students can be enthusiastic exchanges.

\section{Conclusion}

To sum up, the fundamental purpose of foreign language teaching is to achieve intercultural communication and to communicate with people from different cultural backgrounds. In college English teaching practice, teachers must pay attention to the combination of cultural teaching and language teaching: to teach culture in language, teach language in culture, namely in the language teaching at the same time, timely moderately permeable culture teaching, make students cross-cultural communication ability was improved gradually, so that students not only on language communicative competence, and in the cultivation of the intercultural communication level are fully, so as to comprehensively improve the quality of college foreign language teaching, greatly improve the students' intercultural communicative competence.

\section{References}

[1] J·W·Mekinnonetal.,Am.J.Phys.39,2047 — 1052(1972).

[2] A·E·Lawsonetal.,Sei.Edue.58(NO.4),545 — 559(1974).

[3] E.L.Chiappetta,sei.Edue.60(No.2),253 - 261(1976).

[4] Henzhong Hu. Foreign language teaching and culture [M]. Changsha: Hunan Education press, 1997.

[5] Dajin Lin. Research on cultural communication [M]. Fujian people's publishing house,1999 (23): 42-44. 
[6] Juxin Jia. Culture communication studies [M]. Education press, Shanghai,2003 (2): 15-16.

[7] Yunfang Zhao. On intercultural communication awareness of non-English majors [J]. Journal of kunming institute of metallurgy,2006,(2): 26.

[8] Zhihua Shen, Yuzhu Wang, Baojun Xing. Cognitive structure theory and university student selfeducation [J]. Journal of shenyang normal university: social science edition,2006,(3):32.

[9] Wenxian Zhang. Carrying forward the concept of practical education and constructing the pattern of practical education [J]. China higher education,2005,(3-4):7.

[10] Jia Ma. Self-consciousness: the contemporary appeal of the subject of public opinion [J]. Journal of Shenyang normal university: social science edition,2006,(1):140. 